\title{
Amartya Sen és Az igazságosság eszméje
}

\begin{abstract}
Amartya Sen eddigi hatalmas életmúvében az igazságtalanság elleni küzdelem az a szempont, amely mágnesként rendezi össze az őt élete során foglalkoztató problémák nagy részét. A mü rávilágít, hogy milyen etikai szempontok és milyen belső logika kapcsolja egymáshoz a társadalmi választás elmélete, a jóléti közgazdaságtan, a női-férfi egyenlőtlenség, az éhínségek gazdaságtana, a fejlődési közgazdaságtan és számos más területen folytatott kutatásait, hogyan tartozik össze a közgazdaságtani és a filozófiai megközelítés. Tíz évvel ezelőtti könyve magyar fordításának megjelenése jó alkalmat teremt ennek végiggondolására. ${ }^{\star}$ Journal of Economic Literature (JEL) kód: B310, D63.
\end{abstract}

A közgazdasági Nobel-díjas Amartya Kumar Sen a kortárs társadalomtudomány egyik legkiemelkedőbb alakja. Polihisztor, a közgazdaságtan és a filozófia professzora a Harvard Egyetemen, komoly matematikai tudással rendelkezik, esszéiben a szanszkrit irodalomtól a történelmen és közgazdaságtanon át a politikáig terjedö íven kapcsol össze egymástól látszólag távol álló területeket. Számos közgazdasági témakörben alkotott és ért el fontos eredményeket: jóléti közgazdaságtan, a társadalmi választás elmélete, az igazságosság elmélete, a férfi-női egyenlőtlenség, az éhínségek gazdaságtana, fejlődési közgazdaságtan, vagy éppen közegészségügy.

Műveit több mint harminc nyelvre fordították le, közel száz egyetem és akadémia fogadta tiszteletbeli tagjai közé, vagy adományozott neki címet. Igazi közértelmiségi (public intellectual), gyakran nyilatkozik aktuális társadalmi kérdésekröl, vesz részt közéleti vitákban. A szủken vett tudományos életen túlnyúló ismertségét mutatja, hogy 2010-ben a Time magazin a világ 100 legbefolyásosabb embere közé sorolta.

Legnagyobb hatású - egyben legvitatottabb - szellemi terméke a képességalapú megközelítés (capability approach), ez áll a szegénységgel és a szegénység elleni

* A cikk Amartya Sen Az igazságosság eszméje címmel 2021-ben az Osiris Kiadónál megjelent kötete (ford. Felcsúti Péter) utószavának csekély mértékben kiegészített változata (angol eredetit lásd Sen [2010]).

Molnár György a KRTK KTI tudományos főmunkatársa (e-mail: molnar.gyorgy@krtk.mta.hu). A kézirat első változata 2021. február 3-án érkezett szerkesztőségünkbe.

DOI: http://dx.doi.org/10.18414/KSZ.2021.3.300 
küzdelemmel kapcsolatos elemzései központjában. A társadalomtudósoknak abba a csoportjába tartozik, akik úgy foglalkoznak mély elméleti, alapkutatási kérdésekkel, hogy folyamatosan szem előtt tartják a gyakorlati alkalmazás lehetőségét. Munkássága a szegénységgel foglalkozó kutatók számára ma már szinte megkerülhetetlen.

Több méltatója szerint is ő hozta vissza az etikát a közgazdaságtan föáramába. Sen munkásságának izgalmas vonása, hogy többnyire valahol a közgazdasági gondolkodás fóára mának határvidékén helyezkedik el, hol benne, hol azon kívül. Persze a fóáram tartalma sem állandó, és bővüléséhez minden bizonnyal Sen is hozzájárult. Alapos ismerője a klasszikus és a neoklasszikus közgazdaságtannak, Nobel-díját részben olyan eredményekért kapta, amelyek ez utóbbi iskolához sorolhatók. Ugyanakkor a neoklasszikus gondolkodás egyik alapvető fontosságú elemének, a racionális, hasznosságmaximalizáló döntéshozó feltételezésének leginvenciózusabb kritikusai közé tartozik. Kritikai érvelése, a szabadsággal és a szegénységgel kapcsolatos felfogása jelentős hatást gyakorolt a fóáramon kívüli, heterodox közgazdaságtanra is.

Sen 1933-ban született Indiában, a nyugat-bengáli Sántinikétánban, a Magyarországon is jól ismert, irodalmi Nobel-díjas Rabindranáth Tagore apja által alapított egyetem kampuszán. Édesapja vegyészprofesszor volt, anyai nagyapja szanszkritológus, az ókori és középkori India kutatója, Tagore közeli munkatársa. A hindiül halhatatlant jelentő Amartya nevet is Tagore ajánlotta szüleinek.

Interjúiban rendszeresen visszatér két megrázó, gondolkodását és tudományos pályáját is befolyásoló gyermekkori élményére. Az egyik az 1943-as bengáli éhínség, amelyben legalább 2 millió ember halt meg, de egyes becslések szerint a 3 milliót is elérte az áldozatok száma. Eközben ő maga senkit sem ismert rokonai, ismerősei, osztálytársai között, akiket az éhínség akár a legkisebb mértékben érintett volna. Elmondása szerint ekkor tudatosultak benne a hatalmas osztálykülönbségek. A másik az India és Pakisztán 1947-es szétválását, Bengália vallási alapú felosztását kísérő erőszak, a házuknál időnként alkalmi munkát vállaló, kereset reményében a hindu többségű környékre merészkedő muszlim férfi erőszakos halála. Ez az élmény vezette annak megértéséhez, hogy a szegénység nem pusztán gazdasági, hanem társadalmi kérdés is.

Ifjúkorában egy ideig úgy gondolta, hogy a társadalmi egyenlötlenségek, az igazságtalanság ellen küzdő politikus lesz. Ettől egy elvi probléma és egy személyes életesemény tántorította el. Az akkori indiai baloldal számára, akárcsak neki, nagyon fontosak voltak az egyenlőség problémái, a baloldali szerveződések azonban a legjobb esetben is érdektelenek voltak a társadalmi döntési folyamatok demokratikus jellegévek szemben, és kevés toleranciát mutattak a más véleményt vallók iránt, amit viszont Sen központi jelentőségünek tartott.

18 éves korában szájrákot kapott, amit sugárkezeléssel sikerült megszüntetni, de orvosai mindössze 15 százalék esélyt adtak annak, hogy öt évnél tovább él. Később több helyreállító sebészi kezelésre volt szüksége, ami végképp eldöntötte, hogy nem megy politikusnak, de problémája a tudományos életben nem jelentett akadályt. 
Alapvetően két tág problémakör foglalkoztatta Sent tudományos pályája során: a gazdasági és társadalmi egyenlőtlenségek különbözö formái, a szegénység és a szegénység elleni küzdelem egyfelől, illetve az észszerü, toleráns és demokratikus társadalmi döntések lehetősége másfelől.

A doktori disszertációját tartalmazó első könyvét 1960-ban publikálta, azóta összesen 33 kötete - ebből 9 a szerkesztésében, a többit egyedül vagy társszerzővel írta - és számtalan cikke, tanulmánya jelent meg. A Nobel-díjról szóló hivatalos sajtóközlemény az addig megjelent 16 könyvből hármat emel ki három, első pillantásra meglehetősen különbözőnek látszó témakörben: a társadalmi választások (közösségi döntések) és a társadalmi jólét kapcsolata (Collective Choice and Social Welfare - Sen [1970]), a gazdasági egyenlötlenségek (On Economic Inequality Sen [1973]), valamint a szegénység és éhínségek kérdése (Poverty and Famines: An Essay on Entitlement and Deprivation - Sen [1981]). Mindhárom téma fontos szerepet játszik Az igazságosság eszméjében.

Sen az igazságosság, pontosabban az igazságtalanság elleni küzdelem fogalmában találta meg azt a szempontot, amely mágnesként rendezi össze az öt élete során foglalkoztató problémák nagy részét, rávilágít, hogy milyen etikai szempontok és milyen belső logika kapcsolja ezeket egymáshoz. Ebben az értelemben Az igazságosság eszméje a könyv megírásáig terjedő munkássága összegzésének tekinthető.

A társadalmi választások elméletének alapkérdése, hogy miként lehet a társadalom vagy egy szűkebb közösség tagjainak véleményét igazságosan összesíteni. Vagy ha nem is igazságosan, mert az igazságosságot illetően - ahogy azt Az igazságosság eszméje is részletesen tárgyalja - aligha tudunk közös nevezőre jutni, de legalább valamilyen értelemben megfelelő módon. Egy, a matematikában jártas, a filozófia iránt is érdeklődő társadalomtudós számára, mint amilyen Sen, igazi intellektuális kihívást jelentett Kenneth Arrow 1951-böl származó lehetetlenségi tétele (Arrow [1951]). A tétel értelmében, ha kettőnél több lehetőséget kell az egyéni preferenciáknak megfelelöen sorba rendezni, akkor nem létezik olyan döntési mechanizmus, amely minden preferencia-sorrend esetében kielégíti a megfelelöség viszonylag egyszerü és kézenfekvő feltételeit. ${ }^{1}$

Sen számos tételt bizonyított, amelyek pontosítják, finomítják a szóban forgó feltételeket, és maga is bővítette a lehetetlenségi tételek körét. A kötetben is tárgyalt liberális paradoxont a témával foglalkozó irodalom Sen-paradoxonként tartja számon. Ez nem olyan mély tétel, mint az Arrow-féle, célja lényegét tekintve figyelemfelhívó: a jóléti közgazdaságtanban sokáig alapvetőnek, sok tankönyvben még ma is nyilvánvalóan elfogadandónak tekintett Pareto-hatékonysági megközelítést hivatott megkérdőjelezni. A Pareto-hatékonyság elve azt jelenti, hogy akkor tekintünk egy társadalmi állapotot jobbnak, hatékonyabbnak egy másiknál, ha senki sincs rosszabb helyzetben, mint korábban, és legalább egy személy helyzete jobb lett. Ha ilyen javítás nem lehetséges, akkor az adott állapotot optimálisnak tekinthetjük.

Sen erkölcsileg is megkérdőjelezhetőnek, igazságtalannak tartja, hogy optimálisnak vagy akár csak elfogadhatónak tekintsünk egy olyan társadalmi állapotot, amelyben

\footnotetext{
${ }^{1}$ A problémakör magyar nyelvű tárgyalását lásd például Csontos [1997].
} 
a szegényeknek nincs lehetöségük helyzetükön javítani, amennyiben ezt csak azon az áron tehetik meg, ha mások helyzete romlik. A liberális paradoxon viszont olyanok számára is elgondolkodtató érveléshez vezet, akiket ez a szempont kevésbé foglalkoztat. Azt mondja ki, hogy ha a döntéshozatal során ragaszkodunk a Pareto-elvhez, akkor az egyéni döntési szabadság iránti igénynek már lehetetlen eleget tenni. A paradoxon egyik elvi feloldási lehetősége - és itt újra eljutottunk a Sent folyamatosan foglalkoztató egyik probléma gyökeréig -, ha megkülönböztetjük a szabadság kétféle megközelítését: a szabadságot mint lehetőséget arra, hogy megvalósíthassuk azt, amit el szeretnénk érni az életünkben, illetve a szabadság „eljárás” oldalát.

A hagyományos, utilitarista jóléti közgazdaságtan a közösség összesített hasznosságát törekszik maximálni, tekintet nélkül az elosztási szempontokra. Sőt elvileg lehetetlennek tekinti a különféle egyéni hasznosságok összehasonlítását is, csupán az egyes egyének hasznosságának preferencia-sorrendjét használja fel. Ezzel végletekig leszükíti a döntéshozatal információs bázisát. Márpedig nem lehet jó döntéseket hozni, ha a lényeges információk jelentős részét figyelmen kívül hagyjuk.

Sen elismeri a teljes összehasonlíthatóság lehetetlenségét, de számára ebböl nem a teljes összehasonlíthatatlanság következik, hanem keresi a részleges összehasonlíthatóság lehetőségeit. A Nobel-emlékdíj átvételekor tartott ünnepi beszédében ${ }^{2}$ a következőket mondta:

„Példának okáért nem okoz különösebb nehézséget, hogy elfogadjuk, miszerint Néró császár abból adódó hasznosságnövekménye, hogy felégette Rómát, kisebb lehetett, mint a római lakosok hasznosságcsökkenéseinek összege. De ehhez a megállapításhoz nincs arra szükségünk, hogy bizonyosak legyünk benne, hogy mindenki hasznosságértéke egyaz-egy arányban megfeleltethető egymásnak." (Sen [1999] 19. o.)

Alapjában véve ugyanaz a megközelítésmód, mint Az igazságosság eszméjében: még ha nem is tudjuk megmondani, hogy mi $a z$ igazság, azt általában meg tudjuk mondani, ha valami mélységesen igazságtalan.

A döntéshozók információs bázisának szélesítését, az igazságosabb döntések megalapozását szolgálják a szegénység mérésével kapcsolatos munkái is. Ma is a szegénységi küszöb alatt élők számának meghatározása a leggyakoribb mérési módszer. Ez azonban téves szakpolitikai következtetésekhez, igazságtalan megoldásokhoz vezethet, hiszen a szegények száma a legegyszerübb módon és a legkevesebb költséggel akkor csökkenthető, ha csak a legkevésbé szegényeknek segítünk helyzetük javításában, miközben a többiek helyzete nem javul, vagy akár romolhat is. (Számos magyar példát is hozhatunk ilyen jellegü közpolitikai intézkedésekre.) Sen volt az első, aki axiomatikus alapokra helyezte a szegénység mérését, és olyan mérőszámot dolgozott ki, amely a szegénység eloszlását is megfelelő módon veszi figyelembe.

A Sen által kezdeményezett, Martha Nussbaummal közösen kidolgozott, képességalapú megközelítést tekinthetjük ma a hagyományos jóléti közgazdaságtan egyik legfontosabb alternatívájának. Ennek lényege, hogy az egyén helyzetének

\footnotetext{
${ }^{2}$ Amartya Sen 1998. november 8-án tartott ünnepi beszéde Stockholmban, a közgazdasági Nobelemlékdíj átvételekor.
} 
előnyös voltát nem a jövedelme, a rendelkezésére álló javak valamilyen értelemben vett hasznossága vagy éppen az egyén szubjektív jólléte szerint ítéljük meg, hanem az alapján, hogy mennyiben képes olyan életet élni, amelyet joggal tart értékesnek. A társadalom jólléte abban mutatkozik meg, hogy tagjai milyen számukra értékes lehetőségekkel tudnak ténylegesen élni. A szegénység nem más, mint az alapvető képességektől, ténylegesen kiaknázható lehetőségektől való megfosztottság állapota. Ez a megközelítésmód jelentősen kitágítja a szabadság fogalmát is: aki éhezik, aki betegség esetén nem fér hozzá megfelelő egészségügyi ellátáshoz, aki nem tud részt venni a közösség életében, az nem lehet szabad.

Sen elméletének alapszava a capability. Sajnos nincs egyetlen olyan magyar szó, amely ezt pontosan adja vissza. Helyzettől függően jelentheti azt is, hogy képesség, és azt is, hogy lehetőség, illetve a kettőt együtt. Képes vagyok valamit megcsinálni, mert valódi lehetőségem van rá. Talán éppen a Sen által kidolgozott sajátos, gondolatai lényegétől elválaszthatatlan, de magyarra nehezen lefordítható terminológia is szerepet játszik abban, hogy szellemi teljesítménye nem nyerte még el méltó helyét a magyar társadalmi és közgazdasági gondolkodásban. Eddig magyarul egy könyve jelent meg, A fejlődés mint szabadság (Sen [2003]), továbbá néhány írása tanulmánygyüjteményekben és szociálpolitikai szakfolyóiratokban. Sen széles körü tájékozódását mutatja, hogy Kornai János munkásságának alapos ismeretéről tanúskodó tanulmányt írt a Public Choice folyóirat Kornai-különszámába Marxról és Kornainak Marxhoz való viszonyáról. A tanulmány magyar fordítását a Közgazdasági Szemle januári száma közölte (Sen [2021]).

Az utóbbi időben, elsősorban a szegénység enyhítésének témájában, örvendetesen szaporodik azoknak a magyar tanulmányoknak a száma, amelyek Sen elméletén alapuló vagy azt intenzíven felhasználó kutatásokról számolnak be. Ezek azt mutatják, hogy a szegények, a társadalom peremén élö emberek helyzetén javítani kívánó programok tervezése és elemzése során hasznos gyakorlati támpontot is jelent a képességalapú megközelítés. Az igazságosság eszméjének magyar megjelenése remélhetően további lendületet ad ennek a kibontakozó folyamatnak.

\section{Hivatkozások}

Arrow, K. J. [1951]: Social Choice and Individual Values. John Wiley \& Sons, New York.

Csontos LÁszLó [1997]: A politika tanulmányozása és a közgazdaságtan. Közgazdasági Szemle, 44. évf. 7-8. sz. 557-568. o. http://epa.oszk.hu/00000/00017/00029/pdf/csontos2.pdf. Sen, A. [1970]: Collective Choice and Social Welfare. 1. kiadás. Holden-Day, San Francisco, CA. Sen, A. [1973]: On Economic Inequality. Clarendon Press, Oxford.

Sen, A. [1981]: Poverty and Famines: An Essay on Entitlement and Deprivation. Clarendon Press, Oxford.

SEN, A. [1999]: A közösségi döntések lehetségességéröl. (Az 1998. november 8-án, a közgazdasági Nobel-díj átvételekor tartott beszéd). Ford. Csillag Márton-Csorba Gergely. Fordulat, őszi-téli sz. Társadalomelméleti Kollégium, Budapest, 4-52. o. http://tekesek.hu/fordulat/ford99osztel.pdf.

SEN, A. [2003]: A fejlődés mint szabadság. Európa Könyvkiadó, Budapest. 
SEn, A. [2010]: The Idea of Justice. Penguin Books, London.

SEN, A. [2021]: Marx Kornai után. Közgazdasági Szemle, 67. évf. 1. sz. 7-13. o. http://dx.doi. org/10.18414/KSZ.2021.1.7. Angolul: Marx after Kornai. Public Choice, 2020. augusztus 19. https://doi.org/10.1007/s11127-020-00838-x.

\section{Válogatás Amartya Sen publikációiból}

\section{Egyedül vagy társszerzövel írt könyvek idörendben}

Choice of Techniques. Basil Blackwell, Oxford, 1960.

Collective Choice and Social Welfare. Holden Day, San Francisco, 1970.

Guidelines for Project Evaluation. (Társszerző: Dasgupta, P.-Marglin, S. A.) UNIDO, United Nations, New York, 1972.

On Economic Inequality. Clarendon Press, Oxford,1973. Bővített kiadás: On Economic Inequality after a Quarter Century. (Társszerző: Foster, J.) Clarendon Press-Oxford University Press, Oxford-New York, 1997.

Employment, Technology, and Development. Clarendon Press, Oxford, 1975.

Poverty and Famines: An Essay on Entitlement and Deprivation. Clarendon Press, Oxford, 1981.

Choice, Welfare and Measurement. Basil Blackwell, Oxford, 1982.

Resources, Values, and Development. Basil Blackwell, Oxford, 1984.

Commodities and Capabilities. North-Holland, Amszterdam, 1985.

The Standard of Living, Tanner lectures on human values. (Szerk.: Hawthorne, G.; Amartya Sen előadása, továbbá Muellbauer, J.-Kanbur, R.-Hart, K.-Williams, B. hozzászólásai.) Cambridge University Press, Cambridge, 1987.

On Ethics and Economics. Basil Blackwell, Oxford-New York, 1987.

Hunger and Public Action. (Társszerző: Drèze, J.) Clarendon Press, Oxford, 1989.

Inequality Reexamined. Clarendon Press-Russell Sage Foundation at Harvard University Press, Oxford-New York-Cambridge, MA, 1992.

India: Economic Development and Social Opportunity. (Társszerző: Drèze, J.) Clarendon Press, Oxford, 1995.

Development as Freedom. Alfred Knopf, New York, 1999.

Rationality and Freedom. Harvard University Press, Cambridge, MA, 2002.

India: Development and Participation. (Társszerző: Drèze, J.) Oxford University Press, Oxford, 2002.

The Argumentative Indian. Penguin Books-Farrar, Straus and Giroux, London-New York, 2005.

Identity and Violence: The Illusion of Destiny. W. W. Norton-Penguin Books, New YorkLondon, 2006.

The Idea of Justice. Harvard University Press-Penguin Books, Cambridge-London, 2009.

Mismeasuring our lives: why GDP doesn't add up. (Társszerző: Stiglitz, J. E.-Fitoussi, J.-P.) The New Press, New York-London, 2010.

Peace and Democratic Society. Open Book Publishers, UK, 2011.

An Uncertain Glory: India and Its Contradictions. (Társszerző: Drèze, J.) Princeton University Press, Princeton, 2013. 
The Country of First Boys and Other Essays. Oxford University Press, 2015. Collective Choice and Social Welfare: Expanded Edition. Penguin Books, London, 2017.

\section{A szerkesztésében (társszerkesztésében) megjelent kötetek}

Growth Economics. Penguin Books, Harmondsworth, 1970.

Utilitarianism and Beyond. (Társszerkesztő: Williams, B.) Cambridge University Press, Cambridge, 1982.

The Political Economy of Hunger. (Társszerkesztő: Drèze, J.-Hussain, A.) Clarendon Press, Oxford, 1990 és 1991.

The Quality of Life. (Társszerkesztő: Nussbaum, M.) Clarendon Press, Oxford, 1993.

Indian Development: Selected Regional Perspectives. (Társszerző: Drèze, J.) Oxford University Press, Delhi, 1997.

Public Health, Ethics, and Equity. (Társszerkesztő: Sudhir, A.-Peter, F.) Oxford University Press, Oxford, 2004.

Handbook of Social Choice and Welfare. Vol. 1-2. (Társszerkesztő: Arrow, K.-Suzumura, K.) Elsevier/North-Holland, 2002, 2010.

Markets, money and capital: Hicksian economics for the twenty-first century. (Társszerkesztő: Scazzieri, R.-Zamagni, S.) Cambridge University Press, 2008.

Néhány fontos cikk, tanulmány, amelyekre Az igazságosság eszméje címü kötetben hivatkozik

The Impossibility of a Paretian Liberal. Journal of Political Economy, Vol. 78. No. 1. 1970, 152-157. o. https://doi.org/10.1086/259614.

Behaviour and the Concept of Preference. Economica, Vol. 40. No. 159. 1973, 159-241. o. https://doi.org/10.2307/2552796.

Rational Fools: A Critique of the Behavioral Foundations of Economic Theory. Philosophy and Public Affairs, Vol. 6. No. 4. 1977, 317-344. o.

Rights and Agency. Philosophy and Public Affairs, Vol. 11. No. 1. 1982, 3-39. o.

Evaluator Relativity and Consequential Evaluation. Philosophy and Public Affairs, Vol. 12. No. 2. 1983, 113-132. o.

Well-being, Agency and Freedom. The Dewey Lectures 1984. Journal of Philosophy, Vol. 82. No. 4. 1985, 169-221. o. https://doi.org/10.2307/2026184.

Maximization and the Act of Choice. Econometrica, Vol. 65. No. 4. 1997, 745-779. o. https:// doi.org/10.2307/2171939.

Merit and Justice. Megjelent: Arrow, K.-Bowles, S.-Durlauf, S. (szerk.): Meritocracy and Economic Inequality. Princeton University Press, Princeton, NJ, 2000, 4-16. o.

Sraffa, Wittgenstein, and Gramsci. Journal of Economic Literature, Vol. 41. No. 4. 2003, 1240-1255. o. https://doi.org/10.1257/jel.41.4.1240.

Our Past and Our Presence. Economic and Political Weekly, Vol. 41. No. 47. 2006.

The Discipline of Economics. Economica, Vol. 75. No. 300. 2008, 617-628. o. https://doi. org/10.1111/j.1468-0335.2007.00660.x. 


\section{Magyarul megjelent müvei idörendben}

Az egyéni szabadság mint társadalmi elkötelezettség. Esély, 1. sz. 1992, 3-18. o. Megjelent továbbá: Kindler József-Zsolnai László (szerk.): Etika a gazdaságban. Keraban Könyvkiadó, Budapest, 1993, 26-44. o.

Több mint 100 millió nő hiányzik. Tér és Társadalom, 7. sz. 1993, 123-133. o. https://doi. org/10.17649/TET.7.1-2.276.

Van-e az üzleti etikának gazdasági jelentősége? Közgazdasági Szemle, 40. évf. 2. sz. 1993, 101-109. o.

A jövedelemelosztás etikai kérdései: nemzeti és nemzetközi szinten. Megjelent: Csaba IvánTóth István György (szerk.): A jóléti állam politikai gazdaságtana. Osiris Kiadó-Láthatatlan Kollégium, Budapest, 1999, 195-218. o.

A közösségi döntések lehetségességéről. (Az 1998. november 8-án, a közgazdasági Nobeldíj átvételekor tartott beszéd). Ford. Csillag Márton-Csorba Gergely, Fordulat, őszi-téli sz. Társadalomelméleti Kollégium, Budapest, 1999, 4-52. o. http://tekesek.hu/fordulat/ ford99osztel.pdf.

A relatív szegény. Esély, 2-3. sz. 1999, 3-16. o.

A fejlődés mint szabadság. Ford.: Hegedüs Judit. Európa Könyvkiadó, Budapest, 2003.

Kirekesztés és beillesztés. Esély, 2. sz. 2003, 3-14. o.

Társadalmi kirekesztés. Fogalom, alkalmazás és vizsgálat I. és II. Esély, 6. sz. 2003, 3-22. o. és 1. sz. 2004, 3-25. o.

Racionális bolondok. A közgazdaságtan magatartásbeli megalapozásának kritikája. Café Bábel, 55. sz. 2007, 93-106. o.

A kapitalizmus a válság után. Ford. Wessely Anna, BUKSZ, 2. sz. 2009, 187-191. o. http:// buksz.c3.hu/0902/10miapalya.pdf.

A fejlődés mint képességfejlesztés. Megjelent: Scheiring Gábor-Boda Zsolt (szerk.): Globalizáció és fejlődés. Kritikai fejlődéstanulmányok. Szöveggyűjtemény. Nemzeti Civil Alapprogram, Budapest, 2011, 110-128. o.

Részletes önéletrajza a Nobel-díj bizottság honlapján, 1998: https://www.nobelprize.org/ prizes/economic-sciences/1998/sen/biographical/. 